
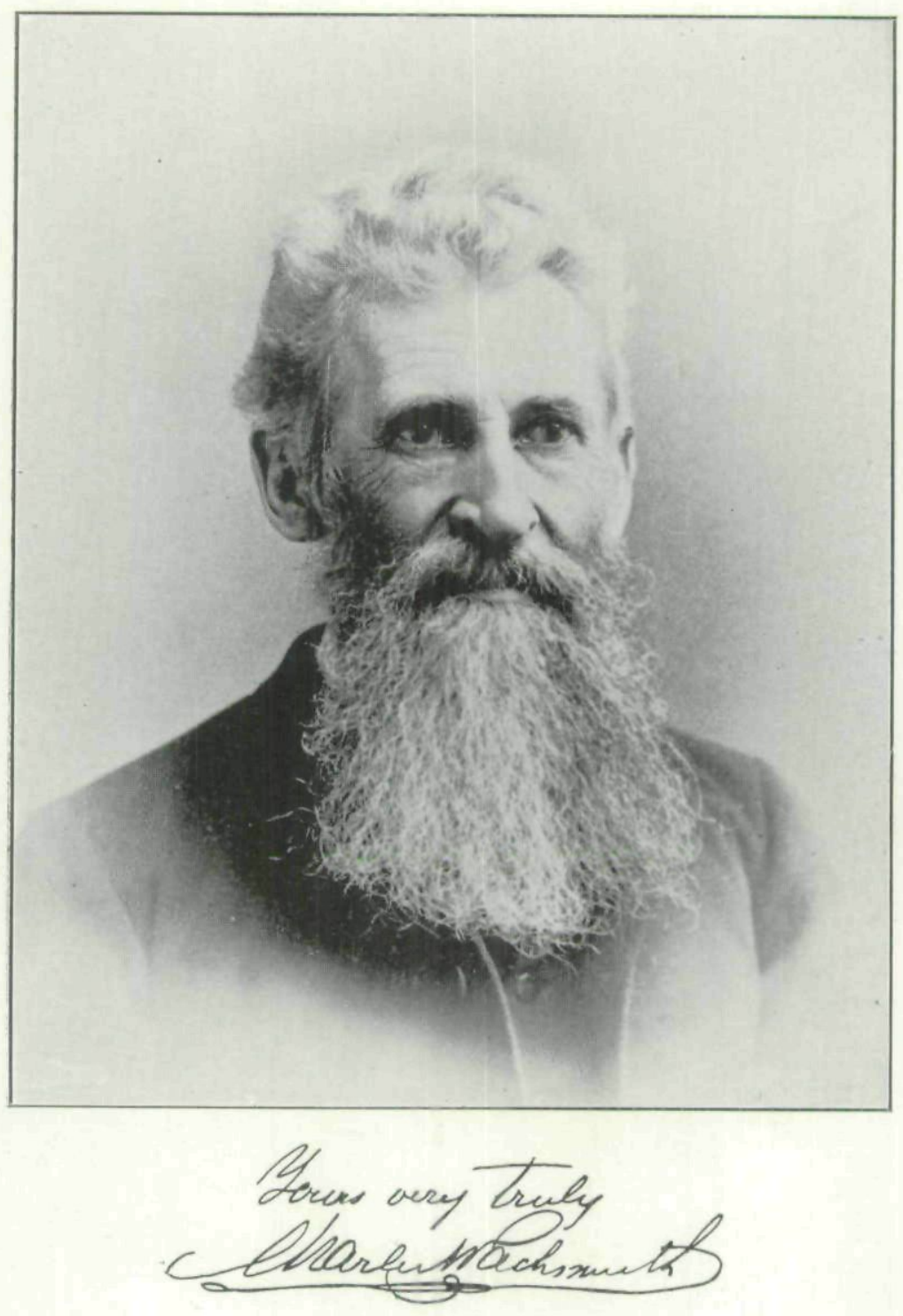


\section{AN EPOCH IN THE HISTORY OF AMERICAN SCIENCE.}

BY CHARLES ROLLIN KEYES, PH. D.

Man's great achievements form the mile-stones of human history. The deeds of a chosen few delimit the periods in a nation's existence. As each of the developmental stages of the world's progress has its eulmination in the unusual ability of some one person, so also in every department of knowledge do the various sections of the cycle begin at the magic touch of some great personality. Physies has its Newton; biology its Darwin; and now dawns a new epoch in the history of an American science.

Few persons living in the great Mississippi valley are aware that one of the most important scientific works ever produced in this country has recently been completed in their very midst. Still fewer Iowans there are, who will not be greatly surprised when informed that the material which served as the foundation for this truly great work was obtained largely within the boundaries of their own State. Yet no contribution to the natural history of the State, of the United States, or of the western hemisphere has surpassed it in importance. Few old world undertakings of similar nature rival it. It stands as one of the master-pieces of American science.

\section{A WOKK OF IOWA SCIENTISTS.}

For more than a quarter of a century, for nearly an entire generation, a work has been quietly carried on within the borders of our commonwealth, slowly, steadily, laboriously, despite of accident, the elements, and ill-health, under unpropitious circumstances, and in face of difficulties well-nigh unsurmountable and obstacles that would have made less courageous hearts to quail. Even men of science 
have only beheld occasional glimpses of the investigation which was being pursued with tireless energy. To the people of the State which has given birth to this work of genius, it has remained unknown. Even the nearest neighbors knew not, much less fully appreciated, what an inquiry was being conducted under their very eyes. Yet with the extreme modesty which seems to grace only the truly great, with the patient toil so characteristic of all grand achievements, and with a philosophic insight which few possess, a scientific treatise has been constructed that will stand a monument for all time to come. The production of one such book each century would be sufficient to keep any star of the Union ever in the rank of those of the first magnitude.

The work to which reference is made is on the North American Fossil Crinoids. It was written by Charles Wachsmuth and Frank Springer. When fully completed it will probably form several large quarto volumes, consisting of plates, of illustrations and letter-press. Of these, the first portion, comprising two large volumes of text and one of plates, has just been issued. The Museum of Comparative Zoology of Cambridge has undertaken to publish the work.

The Crinoids form a group of strange and remarkable organisms which are closely related to the star-fishes and sea-urchins. They differ from these however, in usually being attached by a long stem, or stalk, to objects on the sea bottom. Popularly called "feather-stars," they are among the most beautiful of animals. They closely resemble plants in general shape, and the fossil species are hence widely known as "stone lilies." At the present day only a few forms exist and these are of rare occurrence. In past geological ages, however, they were among the most abundant forms of life. Iowa and the adjoining states were at one time the home of the stemmed feather-stars. At a period just before the coal deposits were formed, a broad, 
shallow, mediterranean sea covered all this portion of the American continent, and throughout its warm, congenial waters, the crinoids flourished in lavish luxuriance. Crinoid life was so prolific at times, that the disjointed skeletal remains formed great beds many feet in thickness and many square miles in extent. One bed in particular which is made up almost wholly of these remains, is one hundred feet thick, and extends unbrokenly in a broad belt a dozen to fifteen miles in width, from central Iowa to western Arkansas, a distance of more than five hundred miles. Some of the layers are hard and compact, while others are incoherent, full of small cavities, and have very little fine or cementing material. Throughout are disseminated the broken and shattered bodies, or calyces, fragments of arms, and portions of stems. In the massive, compact beds, the organic remains have been more or less completely comminuted by the grinding action of moving waters. Yet frequently these layers are separated by clayey or sandy material. Here, lying partly imbedded by the hard limestone are often myriads of stone lilies, perfect as on the day when they were entombed, forms of wondrous beauty and rare delicacy, gracefully and intricately intertwined like rich flowing arabesques. They depict clearly the conditions of their environment at the time when they moved slowly to and fro in the secluded depths of a great interior ocean.

Southeastern Iowa abounds in the beautiful fossils and it is these that have occupied the attention of our Iowa savants for so many years. But it is not alone the description and illustration of these objects that gives the work its great merit and value. It is the vast advance which the study has produced in our knowledge of the structure and of the genetic relationships of the organisms that lend the special scientific charm. It is the great contribution to evolution that the results have brought forth, that places it in the front rank of scientific achievements. It is the 
importance that the group has in the morphological bearing upon the related groups, that raises it to the high plane of philosophic consideration.

For the study of evolution no class of organisms is better adapted. All the changes in structure can be clearly traced from one species to another, from genus to genus, and even from family to family. As the skeletal parts are composed of regular plates, definitely arranged, and frequently highly ornamented, the crinoids have recorded all the marked changes in the physical conditions of their surroundings, both as regards time and space.

The monumental work which has just been published is the out-growth of studies begun under the encouragement and guidance of Prof. Louis Agassiz, and carried on continuously ever since. Geologists from every part of the world have contributed material, until it may be said, without the least fear of contradiction, that the collection of crinoids which are now housed in Iowa, is the largest, most complete and best in existence. So valuable has it become that a large fire-proof building was erected a few years ago to contain it. If a money value could be placed upon it $\$ 100,000,00$ would doubtless be a small estimate of its worth. So famous has it become that it and its modest owners are perhaps better known in all the centers of learning and culture in this country and in the old world, than in the city that claims them as residents. It may be of interest, too, that aside from the cost of the collections and the time of the authors, the expense of publishing the work, for making and reproducing the drawings and printing the plates and text, was over $\$ 20,000.00$.

The state of Iowa may well be proud of this great achievement. The entire work may be regarded as essentially an Iowa production in every sense of the word. Almost all of the material upon which it is based was obtained within the borders of the State. Both the authors 


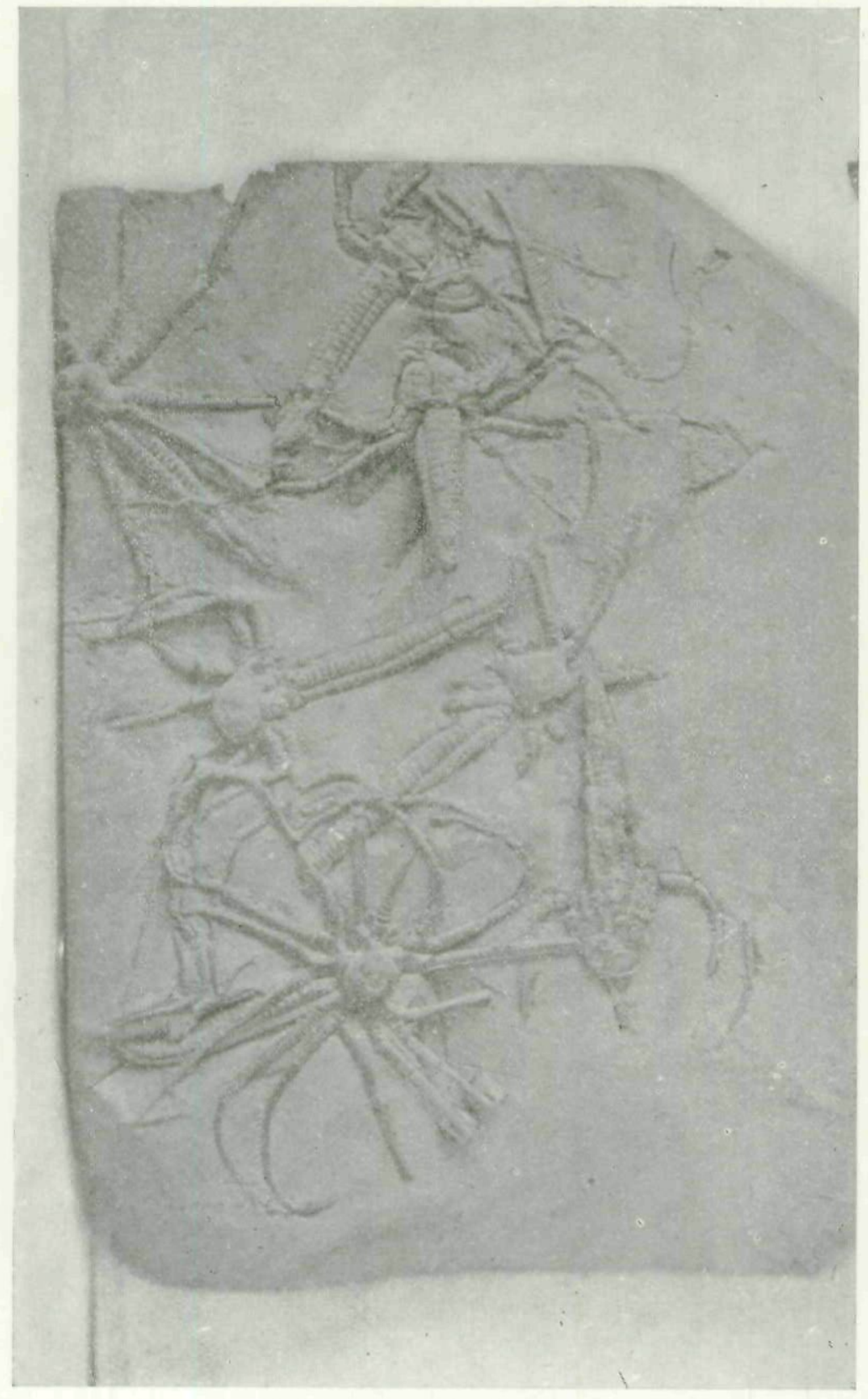

NATURAL POSITION OF CRINOIDS AS FOUND IN ROCK LAYERS. 
are Iowa men, the senior one a resident for more than thirty years, the junior one a native of Louisa county. All the work, from beginning to end, was done in the State, at Burlington. It is to be regretted that Iowa could not have the pride to give birth in print to the grandest scientific and philosophic offspring she ever conceived. A distant state, less slow to perceive the spark of genius, snatches from her the one great honor of a century.

BIOGRAPHICAL SKETCH OF PROF. CHARLES WACHSMUTH.

Charles Wachsmuth, the senior author, was born September 13, 1829, in the city of Hannover, Germany. He was the only son of a lawyer of considerable reputation, who was a member, in 1848, of the German Parliament at Frankfurt. From early childhood he was always in feeble health. It was the wish of his father that he should study law, and he was accordingly sent at an early age to the High School of his native place to receive a classical education; but to his father's great grief and his own, he was obliged, at the age of sixteen, to give up all studies on account of failing health, and on the advice of the attending physician to enter a mercantile carear.

In 1852 the subject of our sketch came to this country, having been sent to New York as an agent of a Hamburg shipping house, in which capacity he served for a period of over two years. This gave him an excellent opportunity to see the great West, which made upon him a very favorable impression. As the climate of New York did not agree with him, he concluded, after barely recovering from a severe attack of pneumonia, and while still very feeble, to try to find relief in the West, by a change of climate. At the suggestion of friends it was decided to go to Iowa, then a young but promising state. The town of Burlington was finally selected as his future home, but without the slighest suspicion of the treasures which were there in store. In $1855 \mathrm{Mr}$. Wachsmuth was 
married, and in the same year embarked in business on his own account. The dry western country did not induce the expected improvement in health, and the consulting physician advised that as much time as possible should be spent in the open air, and that for exercise fossils should be collected. It did not take long for him to develop into an enthusiastic collector, so that days at a time were spent in quarries and ravines around the city, his wife often looking after the store. The new mode of life at once produced a wonderful improvement of health. In the course of a few years a fine collection of crinoids had been brought together. It reached such dimensions that it attracted the attention of eastern scientists. Prof. Louis Agassiz came to see it on his lecturing trip to the West, and Meek and Worthen asked the loan of specimens for description in the geological reports of Illinois which were then being prepared.

In $1865, \mathrm{Mr}$. Wachsmuth closed out his business and accompanied by his wife made a trip to Europe. On his way he visited Cambridge, upon invitation of Professor Agassiz, and saw the large collections in the Museum of Comparative Zoology. Until then he had seen very few crinoids aside from those found at Burlington. His delight knew no bounds as he studied in Cambridge the fossils crinoids from other localities, and a number of specimens of living types. In Europe all sorts of invertebrate fossils were collected and visits made to the principal museums. When England was reached it was a great surprise to find that the reputation of the Burlington collection had already preceded him.

On returning to Burlington, after an absence of almost a year, Mr. Wachsmuth resolved to devote the rest of his life to scientific pursuits, and to direct his whole attention to the crinoids. Living far off from any of the scientific centers, and not having access to the literature, he had to depend for study largely upon his own specimens. This, 
however, proved afterwards an advantage rather than a draw-back, for independent thought and original research. The various state reports to which access could be had gave a superficial knowledge of the principal genera, but they did not throw much light upon the morphology of the class, in which the greatest interest centered. Of great help was a visit of Mr. F. B. Meek, who came to Burlington in the interest of the Illinois Geological Survey to study the collection. During the preparation of the tifth volume of that organization several unique structural specimens were found which seemed to throw light upon the character of the mouth and ambulacra of the ancient forms. The specimens aroused Mr. Meek's interest in a high degree, as proving conclusively that at least in some of the older forms, mouth and ambulacra were subtegminal.

It was in 1873 that Professor Agassiz, on his return from the Pacific coast, paid a second visit to Burlington. He was greatly surprised at the enormous growth of the collection since he had last seen it, and, struck by the beauty and perfection of the specimens, he intimated that he was anxious to procure the collection for Cambridge, at the same expressing a desire to have $\mathrm{Mr}$. Wachsmuth go with it and take charge of all of the crinoids in the Museum. The negotiations were soon completed, and a few months later Mr. Wachsmuth was installed in the Museum of Comparative Zoology as an assistant. It was Professor Agassiz who induced the new assistant to publish the results of his observations under his own name, on the ground that he was doing a great injustice to himself by placing them in the hands of others. The position, which was held until the death of Professor Agassiz, gave ample opportunity for Mr. Wachsmuth to become fully acquainted with the literature on the crinoids, and it was here that the foundation was laid of a classification which divides all Paleozoic crinoids into three primary groups, based chiefly upon the structure of the tegmen. These groups were sketched out 
in 1877 in a paper "On the Internal and External Structure of Paleozoic Crinoids," and they are now recognized as primary divisions with the rank of order.

On returning from a second trip to Europe and a visit to the Orient, in $1874, \mathrm{Mr}$. Wachsmuth had not a single specimen in his possession. It took only a few years to make up another collection that was larger and much superior to the first. A year or two later he made the acquaintance of Mr. Frank Springer, then a young lawyer at Burlington, and an enthusiastic student of the natural sciences. A friendship soon sprung up between them. They studied together, and from 1878 the results of their researches were published under joint authorship. In the following years the collections increased rapidly by extensive purchases. From a trip to Europe Mr. Springer brought home a fine selection of Dudley crinoids, embracing nearly all of the species of that locality, and a large assortment of the Carboniferous species of England and 'Ireland. Among his acquisitions were also rare forms from Belgium, a majority of the Eifel species, fine specimens from Russia and Bohemia, and a large amount of material from Mesozoic and later formations. The collection was enlarged further by extensive exchanges with collectors in this country and Europe, and by having collectors in the field. Liberal purchases for the library were made, and when work was commenced on the monograph, nearly the whole crinoidal literature, from the time of J. S. Miller to date, was at hand. By examining the titles of their publications it will be noticed that Wachsmuth and Springer took very little pride in describing new species, their attention being directed mainly to the morphology with a view to classification, and to the revision of the work of the earlier writers. As the work of the monograph was nearing completion, Prof. Alexander Agassiz, the present director of the Museum of Comparative Zoology, offered to publish it, in the best style possible, as one of the memoirs of the 


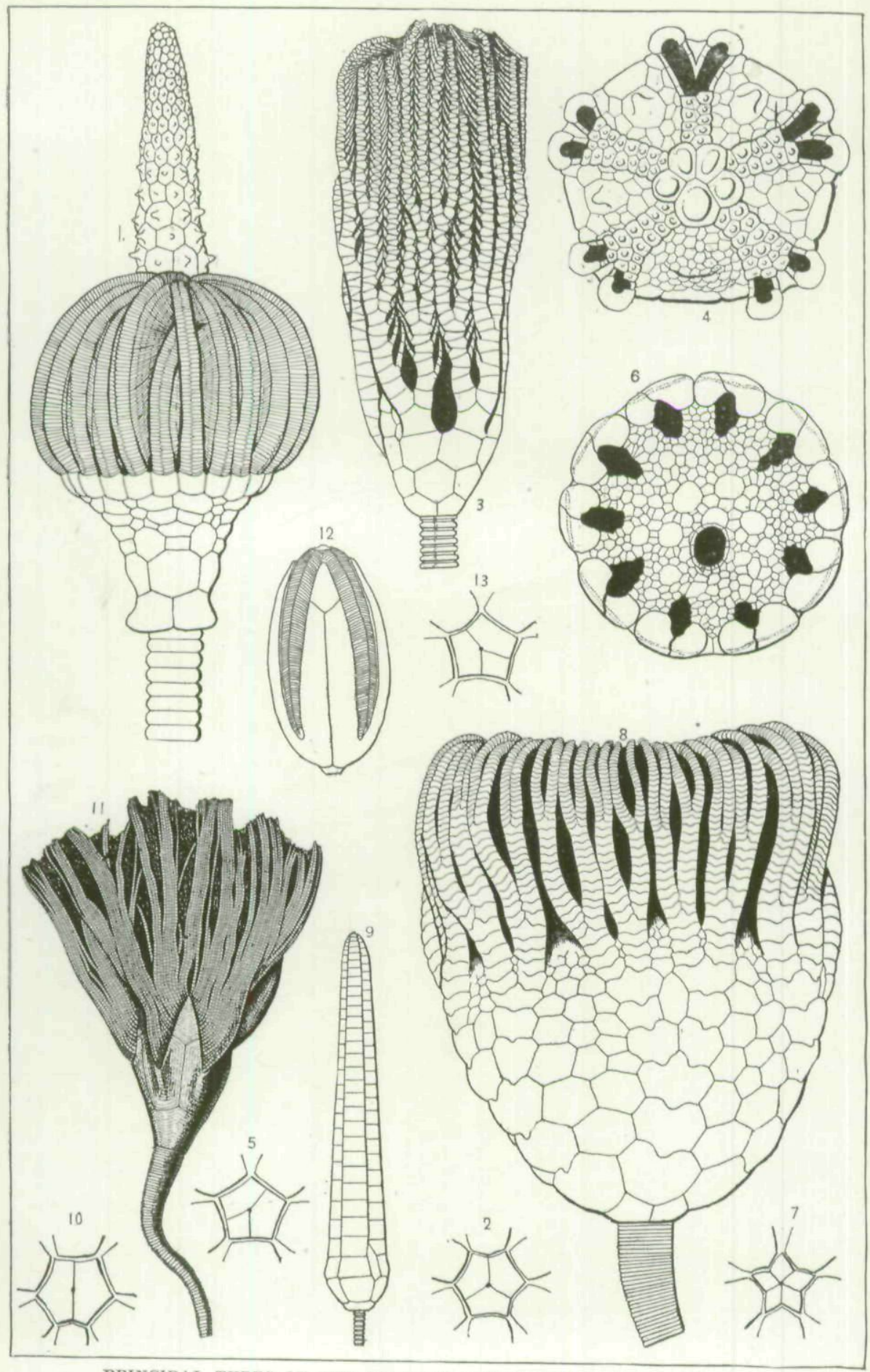

PRINCIPAL TYPES OF THE STALKED FEATHEK STARS, OR CRINOIDS. 
museum, and in this series it now appears, a model of typographic art.

Mr. Wachsmuth is a fellow of the American Association for the Advancement of Science, of the Geological Society of America, the Davenport Academy of Sciences, and the Iowa Academy of Sciences. He was at one time vice-president of the latter. He is also a corresponding member of the Philadelphia Academy of Natural Sciences, and a member of the Imperial Society of Natural Sciences of Moscow, Russia. For many years he has carried on an extensive and intimate correspondence with leading scientists of this country and Europe. That which passed between Dr. P. Herbert Carpenter, the most eminent European authority on Echinoderms, and Mr. Wachsmuth during the past ten years would alone fill a large volume.

For many years Mr. Wachsmuth has been in such delicate health that he has been obliged to spend the winters in the South. The early spring has been passed in the mountains of Alabama, Tennessee and Kentucky, where immense collections of both crinoids and blastoids have been brought together. On all of these trips he has been accompanied by his faithful wife who is herself an excellent and indefatigable collector, an enthusiastic worker, and an admirer of all that pertains to fossil crinoids. Indeed, it may be questioned whether she has not found as many and as rare specimens as the savant himself. Were it not for her tutelary presence the monograph of American crinoids might never have seen the light of day.

Since these pages were sent to press we are called upon to mourn the sudden departure of our friend from the field of his activity. His demise took place on February 7, 1896. By the death of Charles Wachsmuth American Paleontology loses one of its brightest lights. Notwithstanding the fact that he was compelled to lead a retired life and was seldom seen at public gatherings, no one per- 
son did more to raise to the high plane that it now occupies, the department of knowledge which he represented. The world's final judgment as to his true worth to the science must be based upon the monuments he has left.

Although possessing, as already stated, from early childhood a delicate constitution which continually threatened to give away, $\mathrm{Mr}$. Wachsmuth withstood the inroads of an organic disease long enough to nearly complete the allotted span of human life, of three score years and ten. During the last three years his health gradually failed until for several months past herculean efforts were necessary to enable him to work even for a short time each day. His last illness covered only a few days; and even the iron will, which had so often before overcome a long-standing ailment, finally had to give up to the physically weak heart. To within a day of his demise, with a zeal that is begotten only of a love for the sublime, he continued to apply himself to the finishing stages of the crowning glory of his life-the Monograph on the Fossil Crinoids. The first half only was written and the final proofs were barely read when the angel of death beckoned him. The triumphant joy of beholding the completed structure of a noble life's work was not his lot. Deprivation of what he held dearest took the place of conquering satisfaction in the very hour of victory. Inscrutable laws we seek to comprehend, and seeking, seek in vain.

- No better estimate of the Iowa savant could be given than that pronounced, at the gathering to pay the last tribute of respect to his memory, by his intimate friend and long-time collaborator, one who knew him best.

"Many years ago, when recovering from serious illness, our lamented friend expressed a hope that when his time for final parting should come, I, as his friend and associate, might speak some farewell words. I attempt that melancholy duty now, with mingled feelings of sadness that the occasion for it has come, and of thankfulness that it has 
been so long deferred. For, ever since that time, indeed during much of the quarter of a century over which our friendship has extended, he has been fighting against pain and disease in many forms. More than once have we seen his life trembling in the balance, when it seemed as if a feather's weight would turn the scale one way or the other, for hope or despair. The example he has furnished through that protracted struggle, of patient suffering and cheerful fortitude, of high courage, and of iron will which rose superior to his physical infirmities in order that he might leave to science a worthy memorial of his mature and brilliant intellect, is simply sublime.

"There is little need for me, in the presence of these friends who gather around his bier, to speak in words of eulogy of our departed friend. Nothing that I might say could add to the estimation in which he will be held by those who are left behind. The record of his life is before us, and speaks for itself. His personal characteristics which endeared him to every friend, are photographed upon the hearts of all who had the privilege to know him well.

"A man of warm and generous nature; of unyielding fidelity to his convictions of right and truth; tenacious of his opinions, bold in avowing and sturdy in defending them, yet always ready to surrender a theory and accept the proven fact ; scrupulously exact in regard to all his obligations towards his fellow men; his life among you has been an honor to this community, and to the state to which it belongs. It has been a quiet life, without ostentation or display of any kind, even in things of which he had a right to be proud. Most of it for the past twenty years has been spent in the field and the museum, devoted exclusively to the study of Nature and to the solution of problems which she laid before him. Aside from this his chief enjoyment was found in the society of a few congenial friends, by whom the charm of his conversation, the product of his 
rich and varied learning, a fine artistic sense, keen power of observation and a broad and liberal mind, will not soon be forgotten.

"Yet this modest student, in this quiet way, has been erecting a monument which will perpetuate his name in honor and distinction so long as science holds a place among the studies and pursuits of men. A work, too, lat me say, that will cause the name of Burlington to be known and spoken in more, and more distant parts of the world, and by more people of diverse nationality and language, than any event that has happened in her history.

"The thought that comes first to every one of us at this time is that it would have been a kind thing in Fate to allow him to remain a little longer, that he might enjoy the well-earned reward that would come with the completion and distribution of his work, and with the knowledge of its warm reception by the scientific men of the world.

"But the decrees of Fate are inexorable, question them as we may, and from them there is no appeal. The hour for him has struck, but while thus he passes out of our lives, he leaves behind the legacy of his example for our instruction, our encouragement and our emulation. And many a time hereafter, when the tender hand of Time has healed the wounds that bleed to-day, among friends and amid scenes where we know he loved to be, sweet memory will bring him back.

"In this sense it is, my friends, that we may keep him with us yet, until our time is come to cross the mystic river, and explore for ourselves that great mystery which lies upon its far and unseen shore. Let us hope, when that hour shall come that it will find us ready to answer the call with as little fear as he who lies before us. What the future was to be he knew not. He knew that there is a boundary beyond which the human understanding does not pass; that there are infinities of the unknowable of 


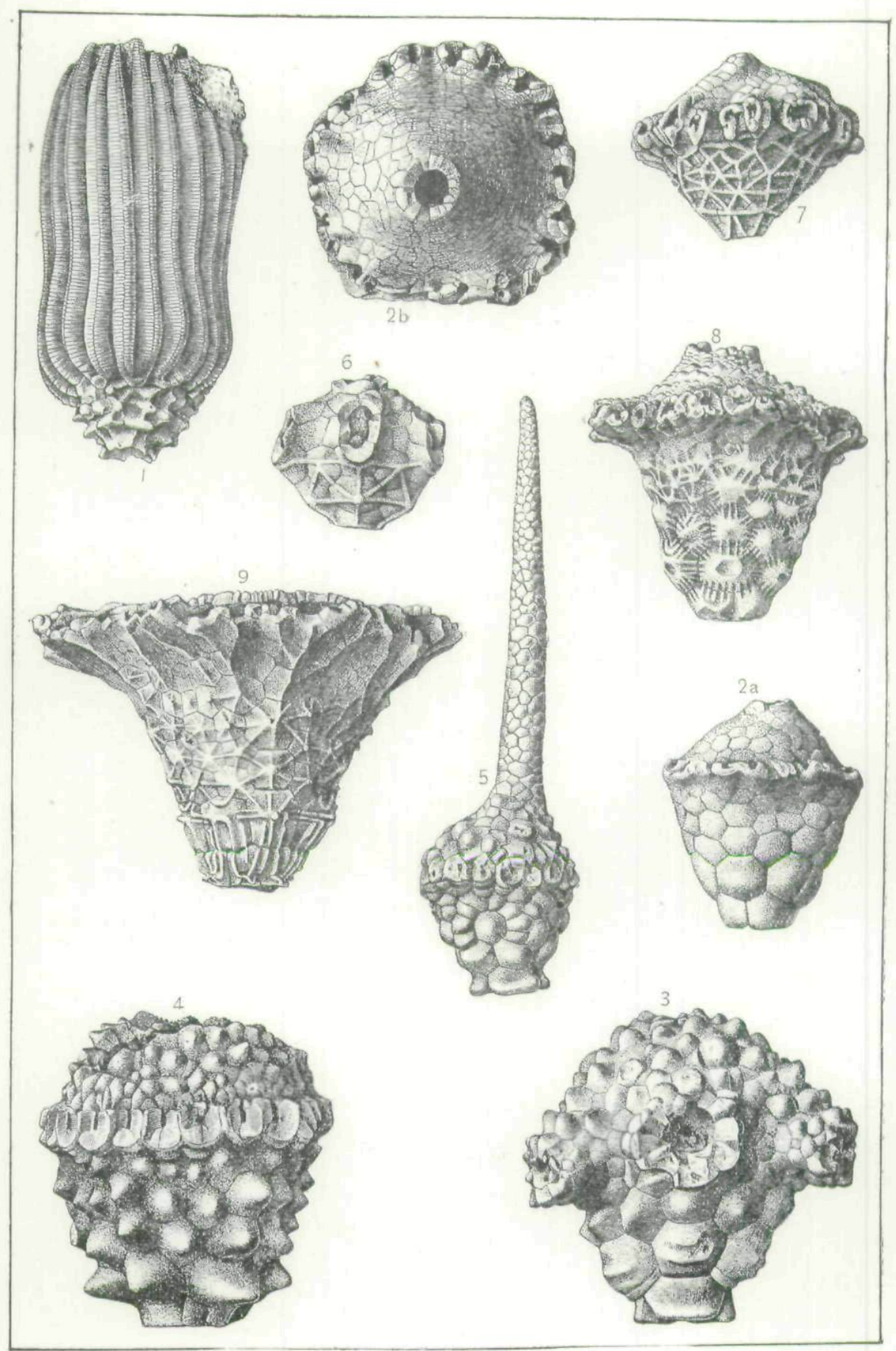

FOSBIL REMAINS OF TYPICAL IOWA CRINOIDS. 
time and space, and force, in whose contemplation human thought is simply swallowed up and lost; that life, death and immortality are mysteries which belong to these, and about which all the researches of science, the speculations of philosophy and the prayers and belongings of men since primeval man first saw the smile of his gods in the sunshine, and in the storm their wrath, have taught us nothing more than to say, we do not know.

"But he believed in the universal order of nature, and that death is simply one of its phases. Whatever might be the power that is above us, he was willing to trust it. And so, having discharged with fidelity his duty to his fellow men, and having done upon earth what his hands found to do, according to the full measure of his talents, he was ready to face the mystery of that future with as calm a confidence as when, at evening, one lies down to pleasant dreams, and awaits the dawning of another day.

"It was written upon the pavement of the temple of Isis: 'I am all that has been, that is, and that shall be ; and 'none among mortals has yet lifted my veil.' Perhaps it is this riddle that we go hence to solve. And let us therefore believe that when death comes to summon us, he does not come in sable garb and with awful countenance, but rather as a smiling messenger from our good old Mother Nature, who takes us to herself again, lifts for us the veil, and with gentle benediction gives us peace and rest."

At the February meeting of the Davenport Academy of Sciences the following was placed upon the minutes:

Resolved, That the Academy has heard with profound regret of the death of Prof. Charles Wachsmuth, an honored member of this Academy, and a valued contributor to the proceedings.

It is fitting that while we record our sense of the loss we have sustained, we should express our appreciation of the great work he has wrought for science in that particular department to which he devoted his life-a work accepted at home and recognized abroad by naturalists engaged iu the same and similar research as one of the most important in the history of geological and paleostological investigation. 
As we call to mind the amount of conscientious labor he performed through a score of years, we wonder how it could have been accomplished while so often battling against disease, with patient suffering, his strong will overeoming physical infirmity and nerving him to fresh devotion to his work.

We may note a marked characteristic of this student of nature. The treasures he gathered at such vital cost to himself were distributed freely and generously to others. All were encouraged to come to him for assistance.

His work accomplished, he passed quietly away in the very locality whose surroundings had at first awakened his early enthusiasm. Remembering the happiness of his home, his affectionate and devoted wife, fit sharer in his labors, and encourager in his work, we extend to her our warmest sympathy in her great aftlietion.

Resolved, That the foregoing resolutions be placed upon the minutes, and copies be sent to the family of the deceased and the press.

REv. W. H. BarRis,

Dr. C. H. Preston,

Committee.

The following are the principal scientific works that have been published by $\mathrm{Mr}$. Wachsmuth chiefly in joint authorship with Mr. Springer:

1866. Evidence of Two Distinct Geological Formations in the Burlington limestone. (Am. Jour. Sei., (2), Vol. XLII, pp. 1-7, 1866 .)

1877. Notes on the External Structure of Palæozoic Crinoids. (Am. Jour. Sei., (3), Vol. XIV, pp. 115-127 and 181-191, 1877.)

1877. Revision of the Genus Belemnoerinus and Description of two New Species. (Am. Jour. Sci., (3), Vol. XIV. pp. 253259,1877 .

1878. Transition Forms in Crinoids. (Proc. Acad. Nat. Sci., Phila., 1878 , pp. 224-266, 1878.)

1879. Revision of the Palæocrinoidea; Pt. I, Iethyocrinidæ and Cyathoerinide. (Proc. Acad. Nat. Sci., Phila., 1878, pp. $226-379,1879$.)

1881. Revision of the Palæocrinoidea; Pt. II, Spæroidocrinidæ. (Proe. Acad. Nat. Sei., Phila., 1881, pp. 177-4i4, 1881.)

1883. Remarks on Glytocrinus and Reteocrinus, two Genera of Silurian Crinoids. (Am. Jour. Sci., (3), Vol. XXV, pp. 255-268, 1883.)

1883. Hybocrinus, Hoplocrinus and Bæroerinus. (Am. Jour. Sei., (3), Vol. XXVI, pp. 365-377, 1883.)

1883. Description of Fossil Invertebrates. (Illinois Geol. Sur., Vol. VII, pp. 339-345, 1883.) 
1883. On a New Genus and Species of Blastoids. (Illinois Geol. Sur., Vol. VII, pp. 346-357, 1883.)

1885. On the Challenger Report on the Stalked Crinoids. (Science, Vol. VI, pp. 138-139, 1885.)

1885. Description of a New Crinoid from the Hamilton Group of Michigan. (Proc. Davenport Acad. Sei., Vol. IV, pp. 94-96, 1885.)

1885. Revision of the Palæocrinoidea, Part III, Section 1. (Proc. Acad. Nat. Seí., Phila., 1885, pp. 225-364, 1885.)

1886. Revision of the Palæocrinoidea, Part III, Section 2. (Proc. Acad. Nat. 'Sci., Phila., 1866, pp. 64-226, 1886.)

1887. Summit Plates in Blastoids, Crinoids and Cystids, and their Morphological Relations. (Proc. Acad. Nat. Sci., Phila., 1887, pp. 82-114, 1887.)

1888. Discovery of the Ventral Structure of Taxocrinus and Haplocrinus, and Consequent Modifications in the Classification of the Crinoids. (Proc. Acad. Nat. Sci., Phila., 1878, pp. $337-362,1888$.)

1888. Crotalocrinus; its Strueture and Zoological Position. (Proc. Aead. Nat. Sei., Phila., 1888, pp. 364-390, 1888.)

1890. Perisomic Plates of the Crinoids. (Proc. Acad. Nat. Sci., Phila., 1590, pp. 345-392, 1890.)

1890. New Species of Crinoids and Blastoids from the Kinderhook Group of Le Grand, Iowa. (Illinois Geol. Sur., Vol. VIII, pp. $157-251,1890$.)

1892. Description of two New Genera and Eight Species of Camerata Crinoids from the Niagara Group. (American Geologist, Vol, X, pp. 134-144, 1892.)

1895. Monograph of the Crinoidea Camerata of North America. (Memoirs of Museum of Comparative Zoology, 2 parts, 800 pp., 83 plates comprising 1500 illustrations, 1895.)

\section{SKETCH OF THE LIFE OF THE HON. FRANK SPRINGER.}

The junior author, Mr. Frank Springer, is a native Iowan, having been born at Wapello, in Louisa county, June 17th, 1848. Graduated from the Iowa State University in 1867 , he immediately began the study of law in the office of Hon. Henry Strong at Burlington. The following year he matriculated with the senior law class in the State University, and was admitted to the bar in 1869. He took up his residence at Burlington, and entered upon the practice of law in the counties of Des Moines and 
Louisa, for which district he was soon after appointed special prosecuting attorney and given charge of most of the criminal prosecutions during the following two years. It was at this period that Mr. Springer was entrusted with the trial of, and successfully conducted, two noted murder cases; State vs. Lawrence, and State vs. Morphy, in both the District and Supreme courts, which, with several important eivil cases in which he was engaged, are reported in the Iowa Reports.

In 1873 , being interested in the proposed extension of the A tchison, Topeka and Santa Fe railroad, then building through Kansas, Mr. Springer removed to the territory of New Mexico, then far beyond railroad communication, and established his residence at Cimarron, a small town in Colfax County. The panic of September, 1873, destroyed all hope of railroad extension for the time, and the construction of the Atchison into New Mexico was postponed for five years. He remained there, however, being employed as attorney for the Maxwell Land Grant Company, a corporation owning a valuable Mexican grant of nearly two million acres of land in New Mexico and Colorado, which afterward became the subject of a famous litigation against the Government in the United States Circuit and Supreme courts, and which was stubbornly contested for many years. The successful conduct of that case, in view of the importance of the question and the magnitude of the property involved, gained for $\mathrm{Mr}$. Springer an enviable reputation at the bar, and his argument in the Supreme court of the United States won for him the personal commendation of the late Justice Samuel F. Miller, both publicly and privately expressed. In 1883 he removed to Las Vegas, where he has since resided. During all the time he has been counsel of the Maxwell Company, and since 1891 has been its president. He has also been counsel for the Atchison, Topeka and Santa Fe railroad company ever since it entered New Mexico in 1878. 


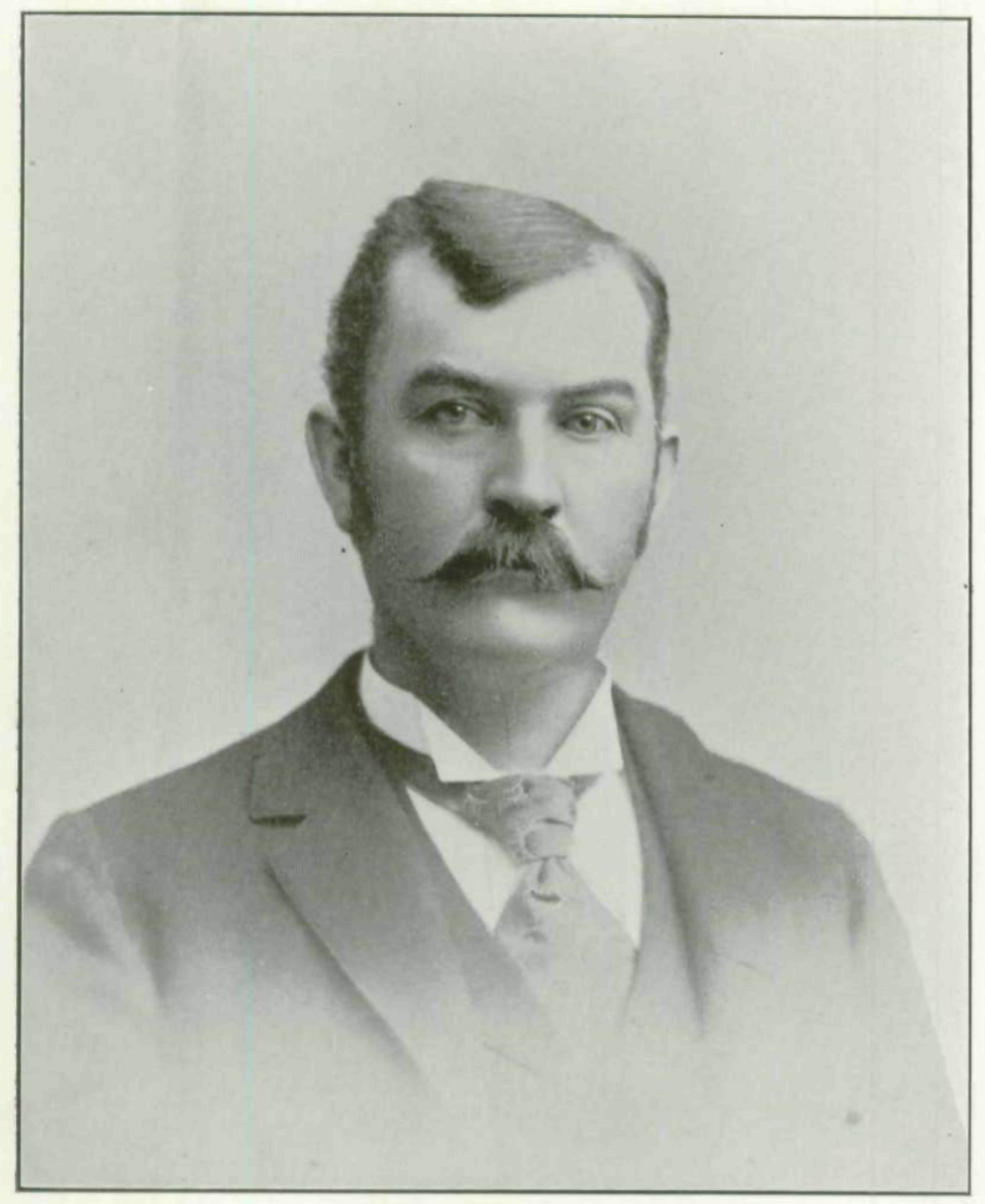

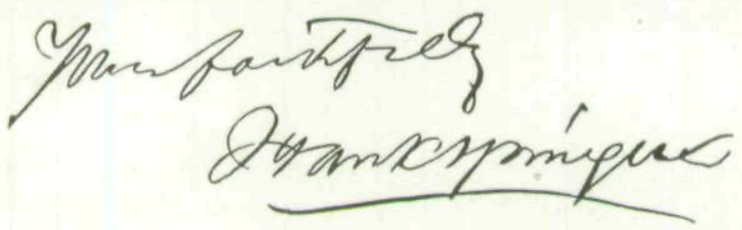


Mr. Springer's position and standing at the bar are shown best by the following authoritative statement furnished by the secretary of the New Mexico Bar Association:

Hon. Frank Springer, of Las Vegas, has been a lawyer in New Mexico since 1873 , when a very young man he cast his lot in a remote part of the Territory, in Colfax county, confident in his ability to grow up with the growing country. His confidence in himself was not misplaced; as a lawyer he has far outgrown his adopted land, and now stands in the front rank of lawyers in the nation while New Mexico lingers far in the rear of the sisterhood of states. Mr. Springer is almost the only lawyer in New Mexico who has escaped politics. He has never held a political position, except one term in the legislative couneil, but has devoted his time, brilliant talent and untiring energy to the profession of the law. Mr. Springer first came into prominence as a lawyer through his eonneetion with the "Maxwell Land Grant" cases, which in one form or another have been before the District, Territorial Supreme Court and Supreme Court of the United States, for the past twenty years, in all of which litigation he has been uniformly suecessful, gaining a very important suit growing out of the Maxwell cases, at the last term of our Supreme Court, which has been taken on appeal to the Supreme Court of the United States. Mr. Springer's practice is almost entirely in large cases and before the Territorial Supreme Court and the Supreme Court of the United States. His counsel is sought on all legal questions of importance, and his advice on constitutional law and private land elaims, is almost anthorative. He was a member of the Constitutional Convention of 1889, and contributed largely to the moulding of that most admirable public paper. In the same year, he was elected President of the Bar Association of the Territory, and his retiring address as such officer is referred to now by searchers for light on land grant law.

While the bar in New Mexico has in proportion to its members as able and brilliant a membership as any within the Union, there is no member who, as a lawyer, citizen and gentleman, in all that those terms imply, is superior to $\mathrm{Mr}$. Springer in the opinion of the bench, bar and people of New Mexico.

From his youth Mr. Springer has been an ardent lover of natural science, and he has managed to find time, in spite of the requirements of an exacting and laborious profession, to keep up the studies begun in early life. It is with this phase of his career that the present sketch has chiefly to do. His taste for scientific studies was formed while a student at the State University, as a pupil of Dr. 
Gustavus Hinrichs, with whom a warm and intimate friendship grew up, and to whose influence, instruction and encouragement he has in later years often expressed his great indebtedness. His special interest in geology and paleontology dates from a lecture and field excursion given to the students of the University by Prof. Louis Agassiz. The personal charm of Agassiz, and his unrivaled facility of explanation, filled the mind of the young student with a desire to understand the science as presented by the great exponent. The facilities for geological study or instruction in Iowa were then of the most meagre description; but in 1866, the headquarters of the state geological survey, under Dr. White, were established at the University, and the collections were brought there for study. Thanks to the kindness of Dr. White and his accomplished assistant, Orestes St. John, Mr. Springer was given access to the collections and the scientific libraries, and became a student of geology and paleontology outside of his regular university course. A strong personal friendship was formed with both these gentlemen, and when they went into the field the following season Springer was left in charge of the state geologist's rooms and collections, and there he passed all his spare time, studying by himself, without instruction, until his graduation. He made a collection of the Devonian fossils of the Iowa City region, and after leaving the University spent considerable time in the field, studying the Lower Carboniferous formations of Louisa county, where he found his noted deposit of fossil fish remains, many of which are described by St. John in volumes VI and VII of the reports of the Illinois Geological Survey. During the preparation of these descriptions, he spent some time in the Illinois State collections at Springfield where he also had access to the great private collections of Professor Worthen.

Upon locating at Burlington, the rich crinoidal fauna of that famous locality naturally attracted his attention, 
and he became an ardent collector, gradually accumulating a large and valuable collection. Here he met his friend Wachsmuth, whose collection of crinoids was then the finest that had ever been made. From collecting they soon began to study together, and thus laid the foundation of the collaboration which culminated in their present work. In the winter of $1872 \mathrm{Mr}$. Springer visited Cambridge, and was given by Professor Agassiz access to the splendid collections of the Museum of Comparative Zoology. It was chiefly owing to the personal encouragement received from Agassiz at this time that he was led to keep up his paleontological studies after leaving Burlington. During his residence in New Mexico he was able to revisit Burlington at frequent intervals, spending his vacations there. Thus he kept up, in connection with Mr. Wachsmuth, the studies they had begun together. These led to the publication of occasional papers jointly, then to the "Revision of the Palæocrinoidea," published by the Philadelphia Academy of Natural Science. They consolidated their collections and libraries, built a large fire-proof museum to contain them, and from time to time afterwards made great additions to both by exchange, purchase, personal collection, and the employment of collectors in different localities; all being done with a view to ultimately bringing out a monograph of the crinoids. Artists were employed for several years making the drawings; and thus the work steadily progressed, until it assumed such proportions that it had to be limited to one division of the group.

In $1887 \mathrm{Mr}$. Springer spent some months in Europe, where he succeeded in obtaining by purchase valuable and much needed material for the work, not obtainable in the United States. He also visited several of the most important collections, especially those of the British Museum, in London, by the authorities of which he was most cordially received. 
In 1890 he went to Cambridge and placed before $\mathrm{Mr}$. Alexander Agassiz the original drawings for the proposed monograph so far as then completed, together with an outline of the plan of the work. After examining them Mr. Agassiz offered to undertake the publication of the work as a part of the Memoirs of the Museum of Comparative Zoology, and placed at the disposal of the authors the entire collections of the Museum, with liberty to remove to Burlington whatever portions of them might be desired. It is well known that Memoirs of the Museum at Cambridge are recognized the world over as containing nothing but original investigations of the very highest order and authority. The fact that the results of the long labors of these Iowa scientists are given to the public under such auspices is the highest evidence of their importance.

The principal scientific writings of $\mathrm{Mr}$. Springer are in collaboration with $\mathrm{Mr}$. Wachsmuth and a list of them is given in connection with the first list.

The Naming of Henry County.-Much interest has lately arisen in regard to the origin of the names of Iowa counties. Among others attention has been attracted to Henry County. It has been stated that it was so named in honor of General Henry Dodge, first territorial governor of Wisconsin. This is doubtless an error. Hon. Alvin Saunders, one of the very early settlers at Mt. Pleasant, a member of the Iowa State Senate from 1854 to 1861 , and later on governor of Nebraska and United States Senator, has lately stated that the county was so named in honor of General James Dougherty Henry, of Illinois. General Henry was not only a prominent actor in the Black Hawk war, but well known and very popular in the west. It is said that he could have had any office in the gift of his state, but that he lost his health from exposure during the war with the Indians and died from consumption in New Orleans, in 1834, having gone south in quest of health. He left no descendants.-Condensed from The Daily Iou Capital, November 6, 1895. 
Copyright of Annals of Iowa is the property of State of Iowa, by \& through the State Historical Society of Iowa and its content may not be copied or emailed to multiple sites or posted to a listserv without the copyright holder's express written permission. However, users may print, download, or email articles for individual use. 